\title{
THE EFFECT OF cis-JASMONE, JASMONIC ACID AND METHYL JASMONATE ON ACCUMULATION OF ANTHOCYANINS AND PROANTHOCYANIDINS IN SEEDLINGS OF COMMON BUCKWHEAT (FAGOPYRUM ESCULENTUM MOENCH)
}

\author{
Marcin HorbowicZ ${ }^{1}$, Halina MiodusZewsKa ${ }^{1}$, \\ DANUTA KOCZKODAJ ${ }^{1}$, MARIAN SANIEWSKI ${ }^{2}$ \\ ${ }^{1}$ University of Podlasie, Institute of Biology, \\ Department of Plant Physiology and Genetics \\ Prusa 12, 08-110 Siedlce, Poland \\ e-mail: mhorbowicz@ap.siedlce.pl \\ ${ }^{2}$ Research Institute of Pomology and Floriculture \\ Pomologiczna 18, 96-100 Skierniewice, Poland
}

(Received: May 26, 2009. Accepted: August 3, 2009)

\begin{abstract}
Effects of various jasmonates (methyl jasmonate, jasmonic acid, cis-jasmone) on anthocyanins and procyanidins content of, as well as on growth of common buckwheat (Fagopyrum esculentum Moench) seedlings were studied. The studied jasmonates were applied as solutions or vapors on four days seedlings, and the seedlings were grown during the next four days in day/night conditions $(16 / 8 \mathrm{~h})$. Afterwards anthocyanins and proanthocyanidins content, as well as elongation of primary roots and hypocotyls were measured. When applied as solutions cis-jasmone (JAS) stimulated the anthocyanins accumulation, but when used as vapors had tendency to decrease its accumulation in buckwheat hypocotyls. Jasmonic acid (JA) solutions slightly stimulated or had no effect on biosynthesis of anthocyanins in buckwheat hypocotyls, but used as vapors caused a decline of anthocyanins in buckwheat hypocotyls. Methyl jasmonate (MJ) clearly inhibited biosynthesis of anthocyanins in hypocotyls of buckwheat seedlings. The studied jasmonates had no influence on anthocyanins level in cotyledons of buckwheat seedlings, except cis-jasmone, which at the lowest solution concentration slightly enhanced biosynthesis of the pigments. Treatment of buckwheat seedlings with solutions of all jasmonates $\left(10^{-8} \mathrm{M}, 10^{-6} \mathrm{M}\right.$ and $\left.10^{-4} \mathrm{M}\right)$ had no influence on the growth of buckwheat hypocotyls. Contrary to that observation vapors of the growth regulators in concentrations $10^{-4} \mathrm{M}$, had a strong inhibitory effect on the growth of hypocotyls of buckwheat seedlings. Solutions of JA and MJ, as well as vapors of JA, MJ and JAS strongly inhibited the primary root growth of buckwheat seedlings, while JAS applied as solution had no such influence. MJ and JA caused much higher stimulation of proanthocyanidin biosynthesis in buckwheat hypocotyls than JAS.
\end{abstract}

KEY WORDS: anthocyanins, common buckwheat, cis-jasmone, jasmonic acid, methyl jasmonate, proanthocyanidins, seedlings.

\section{INTRODUCTION}

Jasmonic acid (JA) and its cyclic precursors, usually named as jasmonates, constitute a family of bioactive oxylipins, which are synthesized from unsaturated fatty acids and regulate a variety of defense responses and developmental processes in plants. The main route of jasmonate biosynthesis is initiated in the chloroplast starting from $\alpha$ -linolenic acid, which is released from membrane lipids by phospholipase and converted to 12-oxo-phytodienoic acid (OPDA) by the action of lipoxygenase, allene oxide synthase, and allene oxide cyclase. OPDA is then transported to peroxisomes where it is converted to 3 -oxo-2-(2'-[Z]- -pentenyl)-cyclopentane-1-octanoic acid. Further conversion yields jasmonoyl-CoA, from which (+)-7-iso-JA is released by thioesterase and spontaneously epimerized to (-)-JA (Westernack 2007). JA may be converted into several derivatives, such like: glucoside, iso-leucine conjugate, methyl ester (MJ) or conjugate to the ethylene precursor 1-amino cyclopropane-1-carboxylic acid (Staswick and Tiryaki 2004; Świątek et al. 2004). cis-Jasmone (JAS) is a product of JA decarboxylation, although the biochemical mechanism of the process is still unknown (Koch et al. 1997; Westernack 2007).

The most recognized jasmonate signal transducers in plants are jasmonic acid and its methyl ester. Stress re- 
sponses that depend on JA signaling include defense against wounding caused by insects and microbial pathogens, as well as responses to UV radiation, ozone, and other abiotic stresses (Browse and Howe 2008; Westernack 2007).

Each of the various jasmonate derivatives, i.e. the free acid, its methyl ester and conjugates have distinct biological effects. Wound response is one of the most-studied pathways of jasmonates in signal transduction, because local wounding stimulates jasmonic acid biosynthesis. It is believed that JA acts as a signal leading to systemic expression of genes encoding proteinase inhibitors, which deter herbivores and in effect immunizes the plant against further herbivore attacks (Franceschi and Grimes 1991). MJ is also important in initiating defensive strategies against both insect predators and herbivores (Browse and Howe 2008). One of the first biological activities observed for jasmonates was the senescence-promoting effect (Ueda and Kato 1980). Although it occurs ubiquitously following JA treatment, monocotyledonous plants are more sensitive. At the same time another physiological effect was found for JA and its methyl ester: inhibition of root growth (Dathe et al. 1981; Corbineau et al. 1988; Staswick et al. 1992).

Another JA metabolite - cis-jasmone, is especially highly active in plant-insect interactions (Birkett et al. 2000; Bruce et al. 2003; Bruce et al. 2008). JAS is highly volatile compared to the other jasmonates like JA and MJ. In bean plants (Vicia faba) JAS caused a significant increase in the production of (E)-ocimene (Birkett et al. 2000). cis-Jasmone also induced production of secondary metabolites in wheat, which are responsible for the plant's defense system against pests and diseases (Blassioli Moraes et al. 2008).

Flavonoids biosynthesis is regulated by a complex interaction between internal and external stimuli such as temperature, light, carbohydrates, water stress and plant hormones.

The biosynthesis proceeds from 4-coumaroyl- and malonyl-CoAs to naringenin chalcone, which is converted into the flavanone naringenin (Winkel-Shirley 2001). Naringenin can be oxidized to form the apigenin or hydroxylated to form a dihydroflavonols. Dihydroflavonols might subsequently be reduced to leucoanthocyanidins along the branch leading to flavan-3-ols, proanthocyanidins and/or anthocyanidins. Proanthocyanidins (PA), also called condensed tannins, occur in a wide range of plants and are the second most abundant natural phenolic after lignin and play an important role in defense against herbivores (Dixon et al. 2005). Recently it was suggested that PA biosynthesis is a component of a general wound response in plants (Arnold et al. 2008). The most common type of proanthocyanidins produce cyanidin upon acid hydrolysis and therefore are sometimes called procyanidins (Santos-Buelga and Scalbert 2000; Tanner et al. 2000).

As was previously published, MJ has a stimulatory effect on anthocyanins accumulation in hypocotyls of lightgrown soybean seedlings (Franceschi and Grimes 1991), in shoots of wild Arabidopsis thaliana (Feys et al. 1994), in detached corollas of Petunia (Tamari et al. 1995), in the stem and leaves of tulips (Saniewski et al. 1998a), in peach shoots (Saniewski et al. 1998b), in cell cultures of Vaccinium pahalae (Fang et al. 1999), in apple fruits (Kondo et al. 2001), in suspension cultures of Vitis vinifera (Zhang et al. 2002), and in shoots of Kalanchoe blossfeldiana (Sa- niewski et al. 2003). However, MJ may also inhibit biosynthesis of anthocyanins, as has been recently found in hypocotyls, but not in cotyledons of young buckwheat seedlings (Horbowicz et al. 2008). MJ applied as solution and as vapors at concentration $10^{-6}-10^{-4} \mathrm{M}$ clearly decreased the level of anthocyanins in buckwheat hypocotyls exposed to light conditions, although the activity of major enzyme in phenylpropanoids pathway - phenylalanine ammonia-lyase (PAL) was not inhibited (Horbowicz et al. 2008). On the other hand, MJ had no influence on the content of particular glycosides of apigenin, luteolin and quercetin in both analyzed parts of buckwheat seedling, but clearly enhanced the level of proanthocyanidins (Horbowicz et al. 2009).

Treatment of buckwheat seedlings with MJ had no effect on length of hypocotyls, but the phytohormone had great influence on the growth of the primary root. Highly concentrated $\mathrm{MJ}\left(10^{-4} \mathrm{M}\right)$ almost stopped the primary root growth of buckwheat seedlings, which was almost five times slower in comparison to control (Horbowicz et al. 2008). Inhibition of the root growth of other plants by MJ and JA was earlier observed (Dathe et al. 1981; Corbineau et al. 1988).

Anthocyanin accumulation is stimulated by various environmental stresses, such as UV and blue light, high-intensity light, wounding, pathogen attack, drought, sugar and nutrient deficiency (see reviews by Grzesiuk et al. 2007, and Grzesiuk et al. 2008; Winkel-Shirley, 2001), and stimulation of its biosynthesis by MJ seems to be evident. Why buckwheat hypocotyls respond to MJ in the opposite manner is not known.

Due to the unexpected effect of MJ on anthocyanins biosynthesis in hypocotyls of buckwheat seedlings we decided to compare the influence on the process of the three main members of the jasmonate family: MJ, JA and $c i s$-jasmone. The aim of these studies was to study the effect of the compounds on accumulation of anthocyanins in hypocotyls and cotyledons of 8-days old buckwheat seedlings, on their growth and content of proanthocyanidins in hypocotyls. Because jasmonates are active as solutions and as vapors, the effects of application of both forms were investigated. According to our knowledge there is no information in available literature on such comparative studies.

\section{MATERIAL AND METHODS}

\section{Plant material}

Seedlings of common buckwheat (Fagopyrum esculentum Moench) cv. Hruszowska were used in this study. Germination was carried out by placing buckwheat seeds between two layers of wet filter paper $(20 \times 10 \mathrm{~cm})$ which were then rolled up and inserted in a 21 jar containing 200 $\mathrm{ml}$ tap water. Ten seeds were germinated in each roll. Germination was carried out in darkness at $24 \pm 1^{\circ} \mathrm{C}$.

After four days, buckwheat seedlings were taken for experiments with particular jasmonates: methyl jasmonate (MJ), cis-jasmone (JAS) and jasmonic acid (JA) (purchased from Sigma-Aldrich), which were dissolved in ethanol. In case of treatment with water solutions the jasmonates were applied at $10^{-8}, 10^{-6}$ or $10^{-4} \mathrm{M}$ concentrations. In the control sample the same volume $(0.4 \mathrm{ml}$ in $200 \mathrm{ml}$ water $)$ of ethyl alcohol was added.

In case of vapor treatments - jasmonates were applied on piece of filter paper which was placed inside of a 21 jar 
containing rolls with seedlings of buckwheat, and the jar was immediately closed tightly with a silicon cover. Ethyl alcohol used for preparing the needed solutions was evaporated at ambient temperature for 5 minutes, before insertion of the filter paper into the jar. A preliminary experiment showed that the loss of investigated jasmonates during that time is negligible (data not shown). After $8 \mathrm{~h}$ pre-incubation in darkness, the seedlings were transferred and grown in solutions or vapors of jasmonates during four days in growth chamber with a $16 \mathrm{~h}$ photoperiod and $65 \pm 5 \%$ relative humidity. Jars containing buckwheat seedlings were tightly closed with transparent caps produced from silicon rubber. Chamber temperature was maintained at $24 \pm 2^{\circ} \mathrm{C} / 20 \pm 2^{\circ} \mathrm{C}$ (day/night). Light conditions were provided by $400 \mathrm{~W}$ high pressure sodium lamps, type PhilipsAgro and photon flux density was $200 \mu \mathrm{mol} \cdot \mathrm{m}^{-2} \cdot \mathrm{s}^{-1}$.

\section{Analyses}

Before and after 4-days light/night photoperiod hypocotyls and root length of buckwheat seedlings were measured. Elongation of hypocotyl and primary root lengths after 4-days exposition on day/night conditions was treated a growth increase. Mean results of hypoctyl and the primary root elongation were obtained from three replicates (ten seedlings per replicate).

The anthocyanins content was determined according to the modified spectrophotometric method of Mancinelli (1984) adapted by Horbowicz et al. (2008). Briefly, plant tissues were extracted with acidified $(1 \% \mathrm{HCl}, \mathrm{w} / \mathrm{v})$ methanol for $24 \mathrm{~h}$ in ambient temperature in darkness, with occasional shaking. The extracts were carefully decanted and their absorbance was measured at $530 \mathrm{~nm}$ (peak of absorption of anthocyanin) and $657 \mathrm{~nm}$ (peak of absorption of chlorophyll degradation products). The formula $\mathrm{A}_{530}-$ $0.25 \mathrm{~A}_{657}$ was used to compensate the absorption of chlorophyll degradation products at $530 \mathrm{~nm}$. Total anthocyanins content was calculated as cyanidin-3-glucoside using 29600 as the molecular extinction coefficient. Analyses were carried out for three or four independent replicates, separately for hypocotyls and cotyledons.

For determination of proanthocyanidins, a method based on the fact that condensed tannins absorbance increased when heated in mineral acid, was used (Quettier-Deleu et al. 2000). Freeze dried buckwheat tissue (10 mg) was hydrolyzed with $4 \mathrm{ml}$ of n-butanol-conc. $\mathrm{HCl}(95: 5, \mathrm{v} / \mathrm{v})$ and $0.2 \mathrm{ml}$ of a $2 \%(\mathrm{w} / \mathrm{v}) \mathrm{NH}_{4} \mathrm{Fe}\left(\mathrm{SO}_{4}\right)_{2} \times 12 \mathrm{H}_{2} \mathrm{O}$ in $2 \mathrm{M} \mathrm{HCl}$. The mixture was incubated at $95^{\circ} \mathrm{C}$ for $60 \mathrm{~min}$. After centrifugation, the absorbance at $550 \mathrm{~nm}$ was measured. Values of absorbance of reaction mixtures were measured before hydrolysis, and subtracted from the absorbance of proanthocyanidins. Absorbance values were converted in proanthocyanidin equivalents using molar absorption coefficient for cyanidin chloride (Quettier-Deleu et al. 2000).

\section{Statistics}

The results reported in the figures and tables are means of three or four replicates. Data were statistically examined by a Newman-Keuls test of least significance difference. The different letters in figures and tables indicate significant differences between treatments with $\mathrm{p} \leq 0.05$ adopted as the criterion of significance.

\section{RESULTS AND DISCUSSION}

Figure 1 summarizes the results of the experiments on treatment of buckwheat seedlings by vapors (A) and solutions (B) for all studied growth regulators: methyl jasmonate (MJ), jasmonic acid (JA) and cis-jasmone (JAS). JAS applied as solutions stimulated biosynthesis of anthocyanins in buckwheat hypocotyls, although in case of concentration $10^{-6} \mathrm{M}$ the influence was not significant vs. control. Contrary JAS applied as vapors had a tendency to decrease anthocyanins accumulation, but no significant effect was observed. Reason or reasons of the various effects of cisjasmone depending on its applied form are unknown. Mechanisms of JAS action as vapor and as solution are probably different.

Biosynthesis of anthocyanins in buckwheat hypocotyls was slightly, ca. $20 \%$, stimulated by low concentrations of jasmonic acid solutions $\left(10^{-8} \mathrm{M}\right.$ and $\left.10^{-6} \mathrm{M}\right)$, but was not affected by $10^{-4} \mathrm{M}$ of JA (Fig. 1B). The effect of JA on accumulation of anthocyanins in buckwheat seedlings was similar to the influence of JAS solutions. Surprisingly, when JA was applied as vapors anthocyanins level in buckwheat hypocotyls declined. In case of highest concentration of JA $\left(10^{-4} \mathrm{M}\right)$ the decline reached ca. 50\% (Fig 1A). A molecule of JA contains the carboxylic group and therefore its solvatation by water enhances solubility of JA as compared to MJ or JAS. JA is a weak acid which possesses a $\mathrm{pK}_{\mathrm{a}}$ of 4.5 (Dathe et al. 1993). In such a situation JA in water is in undissociated form and exists in di-molecular associates. Evaporation of di-molecular JA is probably not possible at all. This is probably the main reason for the various effects of JA applied as vapors and solutions.

When MJ was applied as vapors and as solutions, anthocyanins content in buckwheat hypocotyls decreased (Fig.
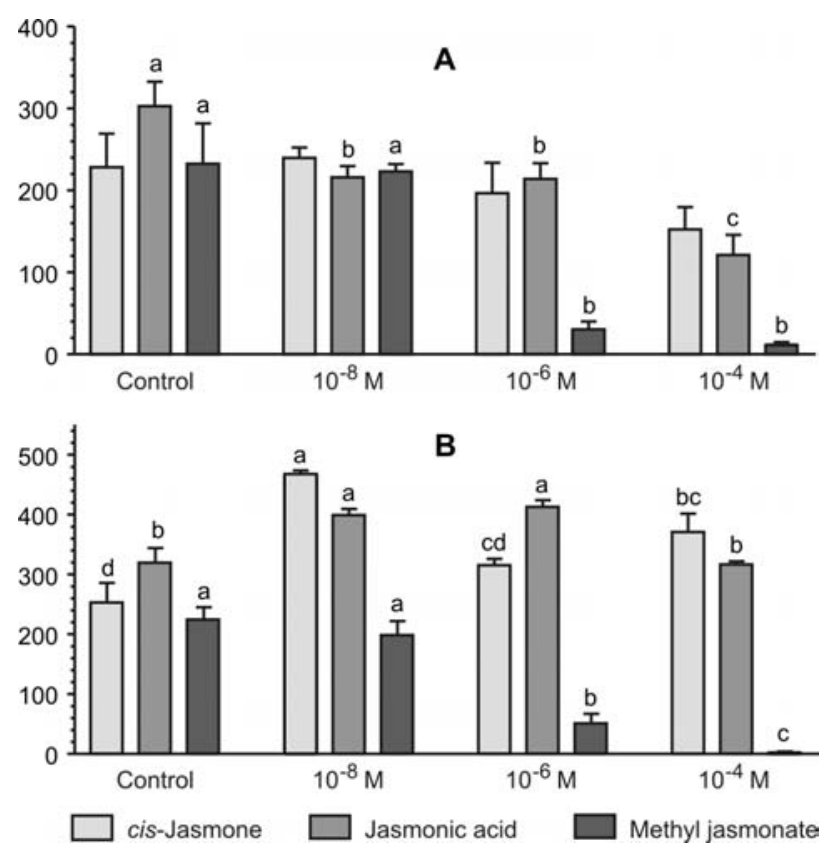

Fig. 1. Effects of four days treatment with jasmonates applied as vapors (A) and water solutions (B) on accumulation of anthocyanins ( $\mu \mathrm{g} \cdot \mathrm{g}^{-1}$ fresh weight; mean \pm SD) in hypocotyls of common buckwheat seedlings. Significance of differences between means were calculated for each jasmonate type separately, $\mathrm{p} \leq 0.05$, Newman-Keuls test. Mean results (bars) marked with various letters were significantly different. No letters above bars means that the results were not significantly different. 

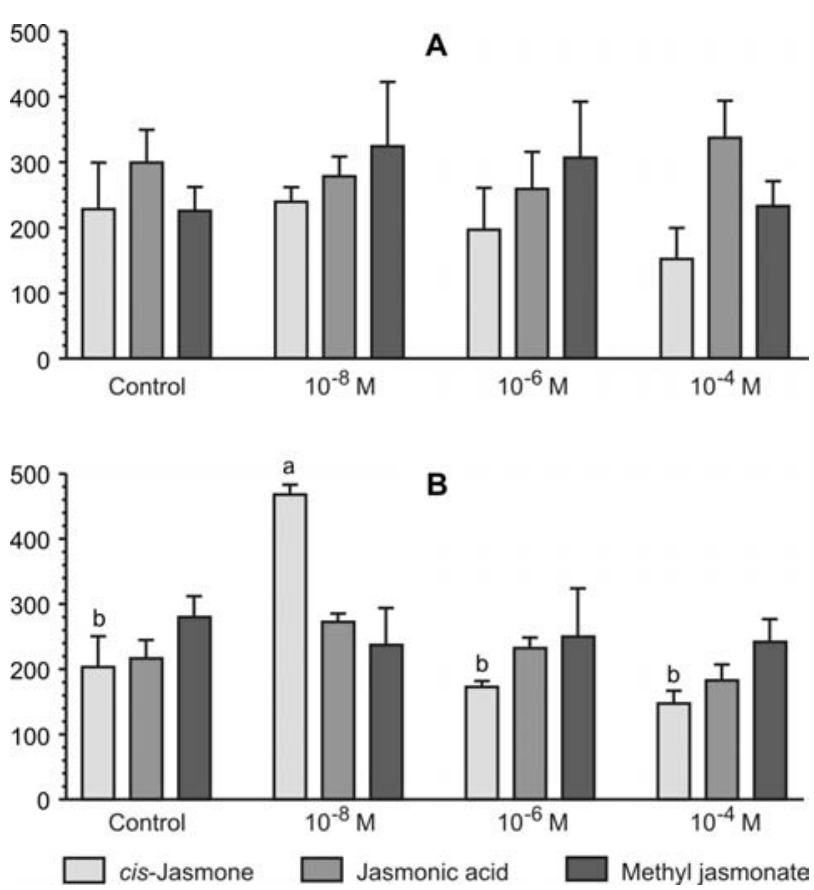

Fig. 2. Effects of four days treatment with jasmonates applied as vapors (A) and water solutions (B) on accumulation of anthocyanins $\left(\mu \mathrm{g} \cdot \mathrm{g}^{-1}\right.$ fresh weight; mean $\pm \mathrm{SD}$ ) in cotyledons of common buckwheat seedlings. Significance of differences between means were calculated for each jasmonate type separately, $\mathrm{p} \leq 0.05$, Newman-Keuls test. Mean results (bars) marked with various letters were significantly different. No letters above bars means that the results were not significantly different.

$1 \mathrm{~A}$ and $\mathrm{B})$. The decline was observed after treatment with $10^{-6} \mathrm{M}$ and $10^{-4} \mathrm{M}$ of MJ. Similar results were obtained in our earlier studies (Horbowicz et al. 2008), but due to different experimental conditions (8 days vs. 7 days old seedlings, light intensity in previous studies was $100 \mu \mathrm{mol} \cdot \mathrm{m}^{-}$ $2 \cdot \mathrm{s}^{-1}$, in present $200 \mu \mathrm{mol} \cdot \mathrm{m}^{-2} \cdot \mathrm{s}^{-1}$ ) we present it for comparison to JA and JAS treatment. In case of treatment with solutions of $10^{-4} \mathrm{M}$ of $\mathrm{MJ}$ only traces of anthocyanins were found in hypocotyls tissue (ca. 1/100 of the control level), and in case of MJ vapors the anthocyanins declined to ca. $1 / 20$ of level observed in control sample. Probably in case of MJ applied as a solution (emulsion) part of the phytohormone can evaporate and treat all plant: roots, hypocotyls and cotyledons. When MJ is applied as vapors only upper plant parts are treated. In another experiment we applied MJ as solutions, but separated it from atmosphere by covering the water with ca. $5 \mathrm{~mm}$ layer of vegetable oil for protection against MJ evaporation. This treatment caused a decline of anthocyanins in buckwheat hypocotyls to $1 / 4$ of control level only (data not shown). Results of the experiment support the hypothesis that MJ can evaporate from a water emulsion.

Differences between influence of JA and MJ on accumulation of anthocyanins in buckwheat hypocotyls can be partly explained through the mode of its translocation in plants. There was strong evidence that MJ moves in both phloem and xylem. Methyl jasmonate moves in tobacco phloem along with photoassimilates, and due to exchange between phloem and xylem is able to move in xylem as well (Thorpe et al. 2007). In contrast, it was reported that jasmonic acid does not exchange between phloem and xylem, probably due to its chemical properties (Zhang and Baldwin 1997).
Studied growth regulators had no influence on anthocyanins level in cotyledons of buckwheat seedlings, except cis-jasmone, which enhanced biosynthesis of the flavonoids when was applied as solution at lowest concentrations $\left(10^{-8} \mathrm{M}\right)$ (Fig. 2A and B). High concentration of cis-jasmone vapor $\left(10^{-4} \mathrm{M}\right)$ had a tendency to reduce the anthocyanins content in buckwheat cotyledons (Fig. 2A).

Because water solutions of cis-jasmone had a tendency to stimulation anthocyanins biosynthesis in buckwheat tissues, and methyl jasmonate was an inhibitor of the process, in another experiment we tried to use them together (Fig. $3)$. The obtained results have shown that JAS did not change the strong inhibitory activity of MJ on biosynthesis of anthocyanins in buckwheat hypocotyls, and in case of applying $10^{-4} \mathrm{M}$ of $\mathrm{MJ}$ and $10^{-6} \mathrm{M}$ of JAS a further synergistic decrease was even noted.

Jasmonic acid $\left(10^{-4} \mathrm{M}\right)$ applied together with cis-jasmone $\left(10^{-8} \mathrm{M}\right)$ caused much clear, ca. $40 \%$ increase of anthocyanins level in buckwheat hypocotyls in comparison to control samples (Fig 4). A similar situation was observed in case of a mixture of $10^{-4} \mathrm{M} \mathrm{JAS}$ and $10^{-4} \mathrm{M}$ of JA. In case of buckwheat cotyledons a strong synergistic effect was noted during application of $10^{-6} \mathrm{M} \mathrm{JAS}$ and $10^{-4} \mathrm{M}$ of JA (Fig. 4).

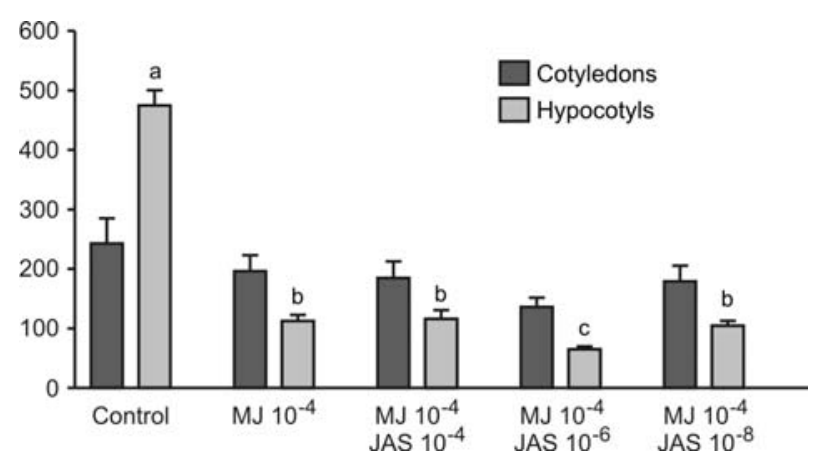

Fig. 3. Effects of four days treatment with mixtures of cis-jasmone (JAS) and methyl jasmonate (MJ) applied as water solutions on accumulation of anthocyanins $\left(\mu \mathrm{g} \cdot \mathrm{g}^{-1}\right.$ fresh weight; mean $\pm \mathrm{SD}$ ) in hypocotyls and cotyledons of common buckwheat seedlings. Significance of differences between means were calculated for each jasmonate type separately, $\mathrm{p} \leq 0.05$, Newman-Keuls test. Mean results (bars) marked with various letters were significantly different. No letters above bars means that the results were not significantly different.



Fig. 4. Effects of four days treatment with mixtures of cis-jasmone (JAS) and jasmonic acid (JA) applied as water solutions on accumulation of anthocyanins $\left(\mu \mathrm{g} \cdot \mathrm{g}^{-1}\right.$ fresh weight; mean $\pm \mathrm{SD}$ ) in hypocotyls and cotyledons of common buckwheat. Significance of differences between means were calculated for each jasmonate type separately, $\mathrm{p} \leq 0.05$, NewmanKeuls test. Mean results (bars) marked with various letters were significantly different. 
TABLE 1. Effects of four-days treatment with jasmonates on elongation ( $\mathrm{mm}$ ) of the hypocotyls and the primary root of seedlings of common buckwheat. Different letters within the same row indicate statistically significant difference at $\mathrm{p} \leq 0.05$ in Newman-Keuls test; * asterics indicate significant effects by treatments in comparison to control at $\mathrm{p} \leq 0.05$ (columns).

\begin{tabular}{|c|c|c|c|c|c|c|}
\hline \multirow{2}{*}{$\begin{array}{l}\text { Applied } \\
\text { concentration }\end{array}$} & \multicolumn{2}{|c|}{ cis-Jasmone (JAS) } & \multicolumn{2}{|c|}{ Methyl jasmonate (MJ) } & \multicolumn{2}{|c|}{ Jasmonic acid (JA) } \\
\hline & vapor & solution & vapor & solution & vapor & solution \\
\hline \multicolumn{7}{|c|}{ Hypocotyls } \\
\hline Control (0) & $34.3 \mathrm{a}$ & $31.6 \mathrm{a}$ & $30.8 \mathrm{a}$ & $31.4 \mathrm{a}$ & $39.7 \mathrm{a}$ & $35.6 \mathrm{a}$ \\
\hline $10^{-8} \mathrm{M}$ & $39.7 \mathrm{a}$ & $32.0 \mathrm{a}$ & $23.3 b$ & $36.0 \mathrm{a}$ & $32.8 \mathrm{a}$ & $36.7 \mathrm{a}$ \\
\hline $10^{-6} \mathrm{M}$ & $28.1 \mathrm{a}$ & $31.2 \mathrm{a}$ & $16.6^{*} \mathrm{~b}$ & $33.3 \mathrm{a}$ & $33.8 \mathrm{a}$ & $31.5 \mathrm{a}$ \\
\hline $10^{-4} \mathrm{M}$ & $10.6 * \mathrm{~b}$ & $31.2 \mathrm{a}$ & $14.0 * \mathrm{~b}$ & $31.5 \mathrm{a}$ & $28.6^{*} \mathrm{a}$ & $36.2 \mathrm{a}$ \\
\hline \multicolumn{7}{|c|}{ Primary roots } \\
\hline Control (0) & $41.4 \mathrm{a}$ & $36.3 \mathrm{a}$ & $36.5 \mathrm{a}$ & $35.0 \mathrm{a}$ & $42.9 \mathrm{a}$ & $43.1 \mathrm{a}$ \\
\hline $10^{-8} \mathrm{M}$ & $50.0 \mathrm{a}$ & $36.7 b$ & $28.8 \mathrm{c}$ & $24.0 * \mathrm{~d}$ & $41.2 b$ & $37.2 \mathrm{~b}$ \\
\hline $10^{-6} \mathrm{M}$ & $42.1 \mathrm{a}$ & $46.2 \mathrm{a}$ & $8.9 * \mathrm{c}$ & $22.3 * b$ & $40.4 \mathrm{a}$ & $23.0 * \mathrm{~b}$ \\
\hline $10^{-4} \mathrm{M}$ & $12.9 * \mathrm{~b}$ & $34.5 \mathrm{a}$ & $5.6^{*} \mathrm{c}$ & $9.0 * \mathrm{c}$ & $33.6 * a$ & $10.3 * \mathrm{~b}$ \\
\hline
\end{tabular}

Treatment of buckwheat seedlings with emulsions of JAS, JA and MJ had no influence on the growth of hypocotyls (Table 1). Contrary to that observation, JAS, JA and MJ vapors in concentrations $10^{-4} \mathrm{M}$ had a strong inhibitory effect on the growth of hypocotyls of buckwheat seedlings (Table 1). It can be possible that all jasmonates vapors induce biosynthesis of defense compounds, like phenolics, which can inhibit a plant growth. It is a well known phenomenon in case of JA and MJ (Saniewski et al. 1998a, b, 2003). Recently it has been found that cis-jasmone also induces production of wheat secondary metabolites, which are responsible for the plant defense system against pests and diseases (Blassioli Moraes et al. 2008).

JA and especially MJ applied as solutions and vapors were strong inhibitors of primary root growth. JAS applied as vapors inhibited root growth as well, however, its solution had no such influence (Table 1). Jasmonic acid applied as solution had higher inhibitory influence on root growth of buckwheat than when used as vapors. The results are similar to our earlier investigations in which it was shown that treatment of buckwheat seedlings with $10^{-8} \mathrm{M}$ emulsion of MJ slightly stimulated the growth of buckwheat hypocotyls, but in higher concentrations $\left(10^{-6} \mathrm{M}\right.$ and $\left.10^{-4} \mathrm{M}\right)$ no influence was observed (Horbowicz et al. 2008). However, even low concentrations of $\mathrm{MJ}\left(10^{-8} \mathrm{M}\right.$ and $\left.10^{-6} \mathrm{M}\right)$ caused ca. $40 \%$ decrease of the primary roots growth. Concentrated MJ $\left(10^{-4} \mathrm{M}\right)$ almost stopped the root growth, which was almost five-times slower in comparison to nontreated buckwheat seedlings (Horbowicz et al. 2008). However during our previous studies the experimental conditions were different, than was described above.

The observed in our studies inhibition by jasmonates, the root growth of buckwheat seedlings was earlier found for a wild Arabidopsis thaliana (Staswick et al. 1992). In their studies the growth of primary root was inhibited at about $50 \%$ when seedlings were placed on agar medium containing 0.1 M MJ. Methyl jasmonate inhibited root and hypocotyl growth of sunflower seedlings, as well (Corbineau et al. 1988). Growth inhibition was one of the first observed biological effects of JA in plants. Jasmonic acid at concentrations $10^{-7}-10^{-5} \mathrm{M}$ rapidly inhibited root growth, and decreased cell elongation in isolated tomato roots cultured in vitro (Tung et al. 1996), and inhibited cytokinin-induced plant growth (Ueda and Kato 1982). Similarly, cis-jasmone vapors inhibited the primary root elongation as MJ did, but its solutions had no influence on the growth of buckwheat seedlings. However, the growth of buckwheat hypocotyls was also strongly inhibited by high concentration of cis-jasmone vapors (Table 1).

Effects of various jasmonates applied as vapors on proanthocyanidins (PA) content in hypocotyls of common buckwheat seedlings are summarized in Table 2. Treatment of buckwheat seedlings with MJ and JA clearly caused stimulation of proanthocyanidins biosynthesis. In case of treatment with methyl jasmonate significant increases of PA content occurred in all applied concentrations: $10^{-8}, 10^{-6}$ and $10^{-4} \mathrm{M}$. Jasmonic acid stimulated PA accumulation in concentrations $10^{-6}$ and $10^{-4} \mathrm{M}$, and cis-jasmone caused such an effect when applied at $10^{-4} \mathrm{M}$ only. The results show that among studied jasmonates MJ is most active, jasmonic acid less active and cis-jasmone the least. Inhibition of anthocyanins synthesis by MJ in buckwheat hypocotyls was accompanied by stimulation of proanthocyanidins formation, which was found in our earlier studies, however under various experimental conditions: duration of hormonal treatment of seedlings, as well as quality and intensity of light (Horbowicz et al. 2009). The plant senescence-promoting effect was one of the first biological activities observed for jasmonates (Ueda and Kato 1980). It seems that an increase in the level of condensed tannins under various jasmonates treatments can be a result of the senescence or aging symptoms in hypocotyls of common buckwheat.

TABLE 2. Effects of four days treatment with jasmonates applied as vapors on proanthocyanidins content ( $\mathrm{mg} \cdot \mathrm{g}^{-1}$ dry weight) in the hypocotyls of seedlings of common buckwheat. Different letters within the same row indicate statistically significant difference at $\mathrm{p} \leq 0.05$, Newman-Keuls test; * asterics indicate significant effects by treatments in compare to control at $\mathrm{p} \leq 0.05$ (columns).

\begin{tabular}{lccc}
\hline $\begin{array}{l}\text { Applied } \\
\text { concentration }\end{array}$ & $\begin{array}{c}\text { cis-Jasmone } \\
\text { (JAS) }\end{array}$ & $\begin{array}{c}\text { Methyl } \\
\text { jasmonate (MJ) }\end{array}$ & $\begin{array}{c}\text { Jasmonic } \\
\text { acid (JA) }\end{array}$ \\
\hline Control (0) & $11.5 \mathrm{a}$ & $11.9 \mathrm{a}$ & $11.5 \mathrm{a}$ \\
$10^{-8} \mathrm{M}$ & $11.4 \mathrm{~b}$ & $15.0 * \mathrm{a}$ & $11.6 \mathrm{~b}$ \\
$10^{-6} \mathrm{M}$ & $11.6 \mathrm{~b}$ & $18.6 * \mathrm{a}$ & $14.1 * \mathrm{~b}$ \\
$10^{-4} \mathrm{M}$ & $14.0 * \mathrm{~b}$ & $18.6 * \mathrm{a}$ & $17.4 * \mathrm{a}$ \\
\hline
\end{tabular}


According to the obtained results MJ affected flavonoids level in seedlings of common buckwheat much more than JA and JAS. The reason for various biological activities of jasmonates depends on the applied form: gaseous or solutions (emulsions). Probably due to poor solubility jasmonates partially evaporate from solution to the atmosphere surrounding the buckwheat seedlings. Concentration of vapors depends on the chemical structure and physical properties of each jasmonate, like for instance its boiling point. According to literature, the boiling point of jasmonic acid is $160^{\circ} \mathrm{C}$ at $0.7 \mathrm{~mm} \mathrm{Hg}$, methyl jasmonate is $110^{\circ} \mathrm{C}$ at $0.2 \mathrm{~mm}$ $\mathrm{Hg}$ and cis-jasmone: $146^{\circ} \mathrm{C}$ at $27 \mathrm{~mm} \mathrm{Hg}$. After extrapolation to normal atmospheric pressure, the theoretic boiling points are as follows: in case of cis-jasmone ca. $270^{\circ} \mathrm{C}$, for methyl jasmonate $330^{\circ} \mathrm{C}$, and $370^{\circ} \mathrm{C}$ for jasmonic acid. Although the boiling point for JAS is lowest, it has a far less influence on the accumulation of anthocyanis and proanthocyanidins in buckwheat hypocotyls then MJ and JA. The effect of cis-jasmone on buckwheat seedlings growth was minor, as well when compared to the influence caused by MJ and JA. Unexpectedly jasmonic acid applied as vapors reduced anthocyanins accumulation, and in contrast JA applied as solution to root zone, had a tendency to increase it. Although JA has a much higher boiling temperature than JAS, it had a much bigger influence on anthocyanins than JAS, when applied as vapor as well as solution. The reason for such a situation remains unknown. We can speculate only that JA after absorption by plant tissue can be partially methylated to methyl jasmonate, and this may be a reason of its greater influence on anthocyanins biosynthesis and growth of seedlings compared to cis-jasmone. Tissues of some plant species (Lycopersicon esculentum, Zea mays, Dryopteris filixmas) treated with JA produce, among other volatiles, methyl jasmonate (Boland et al. 1995). Seo et al. (2001) have cloned a gene encoding an S-adenosyl-L-methionine:jasmonic acid carboxyl methyltransferase (JMT) from Arabidopsis thaliana. Recombinant JMT protein expressed in Escherichia coli catalyzed the formation of methyl jasmonate from jasmonic acid. JMT was expressed differentially in various organs at particular developmental stages and induced by wounding (Seo et al. 2001).

It was suggested that systemic accumulation as well as movement among plants of jasmonates occur via the vapor phase in the form of MJ (Franceschi and Grimes 1991). Alternatively, MJ may diffuse to distal parts of the plant through the phloem to act as a long distance intercellular transducer (Pearce et al. 1991). Probably mechanical damage or water stress facilitates the movement of JA sequestered in the chloroplast to the cytoplasm. However, free acid JA might not be able to move across the cellular membrane without a carrier because of its acidic nature. Therefore the mechanism of conversion of jasmonic acid into methyl jasmonate indicates a possibilty that the JMT is key enzyme for the jasmonates transport throughout whole plants.

\section{ACKNOWLEDGEMENT}

This research was partly supported by grant obtained from Ministry of Science and Higher Education, Poland (grant: N 310040 31/2125).

\section{LITERATURE CITED}

ARNOLD T.A., TANNER C.A., ROTHEN M., BULLINGTON J. 2008. Wound-induced accumulation of condensed tannins in turtlegrass, Thalassia testudinum. Aquat. Bot. 89: 27-33.

BIRKETT M.A., CAMPBELL C.A.M., CHAMBERLAIN K., GUERRERI E., HICK A.J., MARTIN J.L., MATTHES M., NAPIER J.A., PETTERSSON J., PICKETT J.A., POPPY G.M., POW E.M., PYE B.J., SMART L.E., WADHAMS G.H., WADHAMS L.J., WOODCOCK C.M. 2000. New roles for cis-jasmone as an insect semiochemical and in plant defense. Proc. Natl. Acad. Sci. USA 97: 9329-9334.

BLASSIOLI MORAES M.C., BIRKETT M.A., GORDON-WEEKS R., SMART L.E., MARTIN J.L., PYE B.J., BROMILOW R.., PICKETT J.A. 2008. cis-Jasmone induces accumulation of defense compounds in wheat, Triticum aestivum. Phytochemistry 69: 9-17.

BOLAND W., HOPKE J., DONATH J., NUSKE J., BUBLITZ F. 1995. Jasmonic acid and coronatin induce odor production in plants. Angew. Chem. Int. Engl. 34: 1600-1602.

BROWSE J., HOWE G.A. 2008. New weapons and a rapid response against insect attack. Plant Physiol. 146: 832-838.

BRUCE T.J., MARTIN J.L., PICKETT J.A., PYE B.J., SMART L.E., WADHAMS L.J. 2003. cis-Jasmone treatment induces resistance in wheat plants against the grain aphid, Sitobion avenae (Fabricius) (Homoptera: Aphididae). Pest Managment Sci. 59: 1031-1036.

BRUCE T.J.A., MATTHES M.C., CHAMBERLAIN K., WOODCOCK C.M., MOHIB A., WEBSTER B., SMART L.E., BIRKETT M.A., PICKETT J.A., NAPIER J.A. 2008. cis-Jasmone induces Arabidopsis genes that affect the chemical ecology of multitrophic interactions with aphids and their parasitoids. Proc. Natl. Acad. Sci. USA 105: 4553-4558.

CORBINEAU F., RUDNICKI R.M., COME D. 1988. The effects of methyl jasmonate on sunflower (Helianthus annuиs L.) seed germination and seedling development. Plant Growth Regul. 7: 157-169.

DATHE W., KRAMELL H.-M., DAETER.W., KRAMELL R., SLOVIK S., HARTUNG W. 1993. Uptake of jasmonic acid and related compounds by mesophyll protoplasts of the barley leaf. J. Plant Growth Regul. 12: 133-140.

DATHE W., RÖNSCH H., PREISS A., SCHADE W., SEMBDNER G., SCHREIBER K. 1981. Endogenous plant hormones of the broad bean, Vicia faba L. (2)-Jasmonic acid, a plant growth inhibitor in pericarp. Planta 155: 530-535.

DIXON R.A., XIE D.-Y., SHARMA S.B. 2005. Proanthocyanidins - a final frontier in flavonoid research? New Phytol. 165: 9-28.

FANG Y., SMITH M.A.L., PEPIN M.F. 1999. Effects of exogenous methyl jasmonate in elicited anthocyanin-producing cell cultures of ohelo (Vaccinum pahalae). In Vitro Cell Dev. Biol.-Plant. 35: 106-113.

FEYS B.J.F., BENEDETTI C.E., PENFOLD C.N., TURNER J.G. 1994. Arabidopsis mutants selected for resistance to the phytotoxin coronatine are male sterile, insensitive to methyl jasmonate and resistant to a bacterial pathogen. Plant Cell 6:751-759.

FRANCESCHI V.R., GRIMES H.D. 1991. Induction of soybean vegetative proteins and anthocyanin by low-level atmospheric methyl jasmonate. Proc. Natl. Acad. Sci. USA 88: 6745-6749.

GRZESIUK A., DĘBSKI H., HORBOWICZ M. 2008. Wpływ wybranych czynników na akumulację antocyjanów w roślinach. Postepy Nauk Roln. 1: 81-91. (in Polish)

GRZESIUK A., DĘBSKI H., HORBOWICZ M., SANIEWSKI M. 2007. Występowanie, biosynteza i akumulacja antocyjanów w roślinach. Postępy Nauk Roln. 5: 65-77. (in Polish)

HORBOWICZ M., GRZESIUK A., DĘBSKI H., KOCZKODAJ D., SANIEWSKI M. 2008. Methyl jasmonate inhibits anthocyanins synthesis in seedlings of common buckwheat (Fago- 
pyrum esculentum Moench). Acta Biol. Cracov. Series Bot. 52: 71-78.

HORBOWICZ M., WICZKOWSKI W., KOCZKODAJ D., SANIEWSKI M. 2009. Effect of methyl jasmonate on accumulation of flavonoids in seedlings of common buckwheat (Fagopyrum esculentum Moench). Annls. Bot. Fenn. (submitted)

KOCH T., BANDEMER K., BOLAND W. 1997. Biosynthesis of cis-jasmone: a pathway for the inactivation and the disposal of the plant stress hormone jasmonic acid to the gas phase? Helvet. Chim. Acta 80: 838-850.

KONDO S., MOTOYAMA M., MICHIYAMA H., KIM M. 2002. Roles of jasmonic acid in the development of sweet cherries as measured from fruit or disc samples. Plant Growth Regul. 37: 37-44.

MANCINELLI A.L. 1984. Photoregulation of anthocyanin synthesis. VIII. Effects of light pretreatments. Plant Physiol. 75: 447-453.

PEARCE G., STRYDOM D., JOHNSON S., RYAN C.A. 1991. A polypeptide from tomato leaves induces wound-inducible proteinase inhibitor proteins. Science 253: 895-8978.

QUETTIER-DELEU C, GRESSIER B, VASSEUR J., DINE T., BRUNTE C., LUYCKX M., CAZIN M., CAZIN J.-C., BAILLEUL F., TROTIN F. 2000. Phenolic compounds and antioxidant activities of buckwheat (Fagopyrum esculentum Moench) hulls and flour. J. Ethnopharmacol. 72: 35-42.

SANIEWSKI M., HORBOWICZ M., PUCHALSKI J., UEDA J., 2003. Methyl jasmonate stimulates the formation and the accumulation of anthocyanin in Kalanchoe blossfeldiana. Acta Physiol. Plant 25: 143-149.

SANIEWSKI M., MISZCZAK A., KAWA-MISZCZAK L., WE-GRZYNOWICZ-LESIAK E., MIYAMOTO K., UEDA J. 1998a. Effect of methyl jasmonate on anthocyanin accumulation, ethylene production, and $\mathrm{CO}_{2}$ evolution in uncooled and cooled tulip bulbs. J. Plant Growth Regul. 17: 33-37.

SANIEWSKI M., MIYAMOTO K., UEDA J. 1998b. Methyl jasmonate induces gums and stimulates anthocyanin accumulation in peach shoots. J. Plant Growth. Regul. 17: 121-124.

SANTOS-BUELGA C., SCALBERT A. 2000. Proanthocyanidins and tannin-like compounds - nature, occurrence, dietary intake and effects on nutrition and health. J. Sci. Food Agric. 80: 1094-1117.

SEO H.S., SONG J.T., CHEONG J.-J., LEE Y.-H., LEE Y.-W., HWANG I., LEE J.S., CHOI Y.D. 2001. Jasmonic acid carboxyl methyltransferase: A key enzyme for jasmonate-regulated plant responses. Proc. Natl. Acad. Sci. USA 98: 4788-4793.

STASWICK P.E., SU W., HOWELL S.H. 1992. Methyl jasmonate inhibition of root growth and induction of a leaf protein are decreased in an Arabidopsis thaliana mutant. Proc. Natl. Acad. Sci. USA 89: 6837-6840.

STASWICK P.E., TIRYAKI I. 2004. The oxylipin signal jasmonic acid is activated by an enzyme that conjugates it to isoleucine in Arabidopsis. Plant Cell 16: 2117-2127.

ŚWIATTEK A., VAN DONGEN W., ESMANS E.L., VAN ONCKELEN H. 2004. Metabolic fate of jasmonates in tobacco bright yellow-2 cells. Plant Physiol. 135: 161-172.

TAMARI G., BOROVOCH A., ATZORN R., WEISS D. 1995. Methyl jasmonate induces pigmentation and flavonoid gene expression in petunia corollas: A possible role in wound response. Physiol. Plant. 94: 45-50.

TANNER G.J., ABRAHAMS S., LARKIN P.J. 2000. Biosynthesis of proanthocyanidins (condensed tannins). In: Brooker JD (ed.). Proc Austral Centre Int Agric Res: Tannins in livestock and human nutrition, pp. 52-61.

THORPE M.R., FERRIERI A.P., HERTH M.M., FERRIERI R.A. 2007. ${ }^{11} \mathrm{C}$-imaging: methyl jasmonate moves in both phloem and xylem, promotes transport of jasmonate, and photoassimilate even after proton transport is decoupled. Planta 226: 541-551.

TUNG P., HOOKER T.S., TAMPE P.A., REID D.M., THORPE T.A. 1996. Jasmonic acid: effects on growth and development of isolated tomato roots cultured in vitro. Int. J. Plant Sci. 157: 713-721.

UEDA J., KATO J. 1980. Isolation and identification of a senescence promoting substance from wormwood (Artemisia $a b$ sinthium L.). Plant Physiol. 66: 246-249.

UEDA J., KATO J. 1982. Inhibition of cytokinin-induced plant growth by jasmonic acid and its methyl ester. Physiol. Plant 54: 249-252.

WESTERNACK C. 2007. Jasmonates: an update on biosynthesis, signal transduction and action in plant stress response, growth and development. Ann. Bot. 100: 681-697.

WINKEL-SHIRLEY B. 2001. Flavonoid biosynthesis: a colorful model for genetics, biochemistry, cell biology, and biotechnology. Plant Physiol. 126: 485-493.

ZHANG W., CURTIN C., KIKUCHI M., FRANCO C. 2002. Integration of jasmonic acid and light irradiation for enhancement of anthocyanin biosynthesis in Vitis vinifera suspension cultures. Plant Sci. 162: 459-468.

ZHANG Z.P., BALDWIN I.T. 1997. Transport of 2-C-14 jasmonic acid from leaves to roots mimics wound-induced changes in endogenous jasmonic acid pools in Nicotiana sylvestris. Planta 2003: 436-441. 